\title{
At undervise på poststrukturalistisk - undervisning i organisation og ledelse som en selv-refleksiv iagttagelsesmaskine
}

Christa Breum Amh $\phi$, seniorforsker, SLIP-programmet, CBS.

Den offentlige sektor er i krise og skal genopfindes, lyder den danske ledelsesdebat. Lederuddannelser som MPA og Diplom i Ledelse udpeges som svar på, hvordan vi kan skabe de ledere, der med refleksiv distance proaktivt kan sætte præmisserne for, hvordan den skal genskabes. Men hvordan kan vi indenfor de eksisterende undervisningsformer omsætte ledelsesdebatten $i$ en konkret undervisning $i$ organisation og ledelse? Sådan lyder spørgsmålet $i$ nærværende artikel. Artiklen er normativ $i$ den forstand, at den giver et bud på, hvordan undervisning $i$ organisation og ledelse kan designes, så den ikke blot ansporer de studerende til læse og anvende tekster, der handler om at genopfinde den, men også fär et glimt af, hvordan de selv er - og proaktivt kan være - med til at genopfinde, skabe og lede den offentlige sektor gennem deres valg af iagttagelser af organisationen. Artiklen tilbyder ikke ny viden om organisation og ledelse eller nye undervisningsteknikker men viser, hvordan forholdsvis velkendte teknikker ud fra en poststrukturalistisk optik bliver en slags social teknologi. Herfra bliver de ikke neutrale metoder til at formidle eller anvende en ny viden om vores organisationer. Derimod bliver de teknikker, hoormed man som underviser proaktivt kan skabe betingelserne for en ny måde at se på.

\section{Indledning}

Pointen i mange danske bøger om ledelse af den offentlige sektor handler om, at den offentlige sektor i disse år genopfindes (Pedersen, Greve \& Højlund, 2008; Pedersen, 2004; Sløk \& Villadsen 2008; Pedersen, 2011; Melander 2008). Vi ved ikke længere, hvad en "stat", en "kommune" og en "forvaltning" er, og vi ved ikke længere, hvad det vil sige at være en leder, medarbejder og en borger, lyder det. En af grundene er, at vi i disse år ser en eksplosion af styringsteknologier i den offentlige sektor: coaching, værdibaseret ledelse, elevplaner, kontrakter, kompetenceudviklingshjul, MUS, reflekterende teams, selvstyrende teams mm. Disse teknologier kan ikke blot iagttages som neutrale instrumenter, der objektivt kategoriserer, inddeler, måler og evalu- 
erer vores organisationer. De kan også forstås som sociale teknologier (Foucault, 1997), der på forskellige og ofte modstridende måder skaber betingelserne for, hvad en organisation og et medlemskab overhovedet er (Amhøj, 2007; Dean, 1999; Rose, 1999; Tangkjær \& Thygesen, 2004). For Pedersen, Greve \& Højlund ligger "Genopfindelsen [..] ikke i et nyt design eller i en klar reformidé, men snarere i sprækkerne, spændingerne og de strategiske valg, der følger af en stadig mere flydende og internt differentieret sektor, som sættes under pres" (Pedersen, Greve \& Højlund 2008). Der er også andre, der deler diagnosen om, at den offentlige sektor konstant er til forhandling og konstant bliver til og som understreger, at det skaber et solidt styringspres for den enkelte. (Amhøj, 2007; Andersen, 2004; Andersen \& Thygesen, 2004; Dean, 1999; Pedersen, 2004; Rose, 1999). Nogle taler om den polyfone organisation (Andersen, 1999; Rennison, 2004). Det vil sige en organisation, der bliver til gennem en mængde af forskellige koder og diskurser, hvor det ikke længere er muligt at finde en superkode, der binder dem sammen. Enhver kode falder ned ved siden af de andre.

Uanset hvordan studierne viser, at organisationen dukker op på nye måder, stiller det nye krav til lederen, når den formelle organisation tilbagetrækkes, og når de formelle roller ikke på forhånd er givet. Groft sagt kan man sige, at pointen i mange af disse ofte poststrukturalistiske studier af offentlig ledelse handler om, at en leder ikke bare skal være i stand til eksempelvis at kunne trække på dominerende ledelsesdiskurser eller anvende styringsteknologier som coaching, værdibaseret ledelse, kontrakter, årsplaner, reflekterende teams, narrativ ledelse, person- og klientorienteret terapi mm. Lederen skal også kunne iagttage, hvordan ledelsesdiskurserne, styringsteknologierne og sprækkerne mellem dem skaber og leder vores organisationer, fordi de iagttager dem på særlige måder (Tangkjær \& Thygesen, 2004). Det er ledernes iagttagelse af deres egne iagttagelse som konstituerende for praksis, der skaber ledernes handlekraft, synes den minimale præmis at lyde i disse studier (Andersen, 2003; Tangkjær \& Thygesen, 2004; Amhøj, 2007; Pedersen, Greve \& Højlund, 2008). Det er det blik for iagttagelse, der gør, at de proaktivt kan vælge, hvordan de så vil skabe organisationen i dette mylder af koder og diskurser. ${ }^{1}$ I denne artikel vil jeg

\footnotetext{
${ }^{1}$ Det kommer også til syne på forskellige uddannelser, der har fag, der handler om organisation og ledelse. Her er overblik over teori om styringsteknologier og styringsteknologiers konstituerings - og handlekraft eksempelvis i centrum for analyse. Se eksempelvis studieordninger for faget Styringsteknologiernes former på CBS (2009) og Pædagogiske Psykologiske perspektiver på Intervention på DPU (2009) eller en konkret evaluering af MPA uddannelsen (Pedersen \& Nielsen, 2011). Der er naturligvis også andre og konkurrerende perspektiver på den offentlige sektor, der ikke tager afsæt i poststrukturalistiske perspektiver, men det vil være at gå for langt at gå i dybden med dem her. Det, artiklen vil fo-
} 
skrive mig ind i diskussionerne om vores lederuddannelser og i vores diskussioner om undervisning i organisation og ledelse samtidig med, at jeg vil være i "periferien" af dem. Udgangspunktet for denne artikel er nemlig hverken en analyse, evaluering eller en beskrivelse af MPA, Diplom i Ledelse eller kreative partnerskabsprojekter i kommunerne (se eksempelvis Helth, 2011). Derimod vil jeg med afsæt i de eksisterende rammer, der er, som underviser på et universitet, spørge: Hvordan kan vi ikke bare undervise i ovenstående poststrukturalistiske perspektiver på ledelse, men også tilrettelægge og designe en undervisning poststrukturalistisk således, at vi kan anspore de studerende til at blive 'selv-refleksive iagttagelsesmaskiner', der kan iagttage, hvordan deres valg af iagttagelse er med til at forme og skabe den offentlige sektor og i den forstand er med til at genopfinde den? Artiklens væsentligste bidrag er ikke nye undervisningsteknikker men derimod et blik for, hvordan forholdsvise velkendte undervisningsteknikker som undervisningsbeskrivelse, intro, cases, spejling i grupper og dét at læse undervisningen bagfra kan bruges i en poststrukturalistisk optik, hvor det ikke handler om at anvende teorier på praksis eller at få kendskab til mere teori. Det, det handler om, er derimod, hvordan man kan etablere et særligt blik på organisationen (Andersen, 2003). Artiklen vil vise, hvordan nedenstående undervisningsteknikker kan bruges til at konstituere undervisningen som en selvrefleksiv iagttagelsesmaskine:

Figur 1

\begin{tabular}{|l|l|}
\hline Undervisningsteknik & Mål \\
\hline Personlig fortælling & $\begin{array}{l}\text { At skabe distance til organisationsteori som et spørgsmål om at lede efter de } \\
\text { rette modeller, intentioner, essenser og kulturer. At anspore de studerende } \\
\text { til at knytte an til en undervisning, der handler om at iagttage iagttagelser } \\
\text { som iagttagelser, der gør en forskel for organisationen, dens problemer og } \\
\text { løsninger. }\end{array}$ \\
\hline Tre analysestrategier & $\begin{array}{l}\text { At skabe den iagttagelsesmaskine der ansporer de studerende til konstant at } \\
\text { forstyrre, destabilisere og forskyde deres blik på organisationen og at få dem } \\
\text { til at se, hvordan det gør en forskel for, hvilke problemer og løsninger de ser. }\end{array}$ \\
\hline En case & $\begin{array}{l}\text { At anspore de studerende til knytte an til iagttagelsesmaskinen og dermed } \\
\text { ambitionen om konstant at forskyde iagttagelsespositionen. At få dem til at } \\
\text { blive til skarpladte iagttagelsesmaskiner. }\end{array}$ \\
\hline $\begin{array}{l}\text { Ekspertpanel/spejling } \\
\text { i grupper }\end{array}$ & $\begin{array}{l}\text { At anråbe dem som handlekraftige studerende, der kan iagttage organisation } \\
\text { - og efterfølgende iagttage deres iagttagelser som iagttagelser, der gør en } \\
\text { forskel. }\end{array}$ \\
\hline $\begin{array}{l}\text { At læse undervisnin- } \\
\text { gen bagfra }\end{array}$ & $\begin{array}{l}\text { At synliggøre den poststrukturalistiske metapræmis som har struktureret } \\
\text { undervisningen. Eksplicitering kan anspore de studerende til at bevæge sig } \\
\text { fra første ordens til anden ordens iagttagelser og til at bruge denne bevægel- } \\
\text { se (fra den nære til den distancerede iagttagelse) til selv proaktivt at skabe og } \\
\text { genopfinde organisationer. }\end{array}$ \\
\hline
\end{tabular}

kusere på, er nemlig, hvordan vi kan omsætte ledelsesdebatten, som den er skitseret her, i forhold til undervisning i ledelse og organisation. 
Analysen af, hvordan jeg har brugt teknikkerne til at skabe præmisserne for undervisningen, giver mulighed for, at man som underviser gennem sine valg af teknikker kan arbejde proaktivt med at sætte præmisserne for "videnproduktionen" som en produktion af iagttagelser af iagttagelser og med at "produktionsmedlemmerne" bliver til selv-refleksive iagttagere.

Samtidig åbner perspektivet op for, at der er lighedspunkter mellem at være underviser og at være leder. Begge dele handler om at bane vejen for at iagttage iagttagelser som iagttagelser, der sætter en konstituerende forskel. Artiklen vil afslutningsvis perspektivere designet af undervisningen ved at vende grundproblematikken på hovedet og spørge: Hvilke konsekvenser har undervisningen som denne "selvrefleksive iagttagelsesmaskine" så i forhold til ledelsesdebatten?

\section{Det empiriske materiale og hvad kan det sige noget om?}

Rammen for den undervisning, jeg om lidt vil begrunde, udfolde og analysere, er Danmarks Pædagogiske Universitetsskole i år 2009. Undervisningen var en del af kandidatuddannelsen i pædagogisk psykologi og udgjorde et kursus på uddannelsens modul 3, der bærer titlen "Subjektivering, læring og diversitet", hvor et tema i forløbet er organisationsteori. I alt deltog 125 studerende. Titlen for undervisningen var "Organisationen iagttaget fra et poststrukturalistisk perspektiv". Undervisningen var sat til 6 timer på én dag. Den blev superviseret af en kollega fra et andet universitet $\mathrm{i}$ forbindelse med mit adjunktpædagogikum. Eksemplerne i artiklen tager primært afsæt i mine egne overvejelser og design af undervisningen, min kollegas observationer og samtaler med de studerende på holdet. Jeg er ikke interesseret $\mathrm{i}$ at evaluere, måle eller på anden måde kategorisere, hvorvidt den konkrete undervisning var en succes eller ej. Det, der er i fokus i artiklen, er udelukkende en analytisk interesse for, hvordan forholdsvis velkendte undervisningsteknikker kan italesættes, designes og sammensættes ud fra en poststrukturalistisk optik i forhold til at skærpe de studerendes blik for iagttagelser som konstituerende for organisationen. Hvordan skaber de betingelserne for iagttagelserne og for iagttagelserne af iagttagelser? Det er det, der er interessant at belyse i forhold til det empiriske materiale.

\footnotetext{
Metateoretisk udgangspunkt - fra anvendelse til undervisningen som en iagttagelsesmaskine

Ledelsesdebatten (som skitseret ovenfor) og den poststrukturalistiske metapræmis har, som vi nu skal se, konsekvenser for, hvordan man kan tænke og designe en undervisningsgang, der i studieordningen, handler om at give de studerende indsigt $\mathrm{i}$ organisationsteori. Groft sagt kan man sige, at det bliver relevant at designe undervisningen således, at de studerende får blik for, hvorvidt og hvordan vores viden om organisationer ikke blot er en neutral afspejling af verden "derude" men også er med til at skabe organisationer og dermed også vores organisatoriske problemer og løs-
} 
ninger på særlige måder, der udelukker andre. Med det valgte perspektiv bliver det centralt at forskyde undervisningen fra, at vi diskuterer teorier om organisation og ledelse i forhold til, hvad der er mere eller mindre rigtigt og sandt i forhold til vores egne og andres erfaringer, praksis eller viden om virkelige organisationer "ude" i verden til at handle om, hvordan vores valg af iagttagelse konstant er med til at skabe og ja "genopfinde" vores organisationer og vores leder og medarbejderpositioner på særlige måder. Set ud fra et læringsperspektiv kan man sige, at dét, der bliver relevant, ikke er at tilegne sig mere eller bredere viden om "organisationen" eller om at effektivere overførsel af denne viden til de studerende. Med den tyske systemteoretiker Niklas Luhmann kan man sige, at det handler om at skabe den iagttagelse, der kan skabe de studerende, der konstant kan forstyrre deres egen iagttagelsesposition. Luhmann kalder det iagttagelse af anden orden. På den måde gør den poststrukturalistiske metapræmis op med det, nogen kalder tankpasserpædagogik (Keller \& Stegeager, 2011: 243), hvor læreren ses som den, der skal fylde intellektuelt brændstof på eleven, hvorefter den enkelte skal bære det fra klasserummet ud i praksis. Perspektivet gør også op med det Donald Schön kalder den tekniske rationalitet, der handler om, at uddannelsessystemet forstår sin pædagogiske opgave som et spørgsmål om applikation (Schön, 1987). Det vil sige, den studerende skal tilegne sig generaliserede metoder eller teorier som de efterfølgende kan anvende i praksis. Denne type af 'single loop ' læring (Argyris \& Schön, 1996) er også dominerende på mange lederuddannelser (se Pedersen \& Nielsen, 2011: 288 for den pointe). Det valgte perspektiv forsøger også at gå lige til kanten af perspektivisme (Pedersen \& Nielsen, 2011) og 'double loop' learning (Argyris \& Schön, 1978) forstået som det, at få de studerende til at diskutere forskellige teoretiske perspektiver i forhold til organisationen. Man kan sige, at perspektivisme såvel som 'double loop learning' handler om at kunne anvende forskellige teorier og om at kunne genkende mønstre i praksis med henblik på at ændre disse mønstre. Med afsæt i Niklas Luhmann vil jeg vise, hvordan iagttagelse på anden ordens niveau handler om at anspore de studerende til at få blik for, hvordan de selv - gennem deres valg af iagttagelse af organisationen er med til at konstituere den, dens roller, relationer, opgaver og løsninger. Der er naturligvis ikke tale om et enten/eller, men det er særligt den sidste del: Den studerende som 'den selv-refleksive iagttagelsesmaskine', der lægges vægt på i denne artikel. Det baner nemlig samtidig vejen for den præmis, at den studerende kan få blik for, hvordan hun selv er med til at skabe præmisserne for organisationen gennem 
hendes valg af iagttagelse. ${ }^{2} \mathrm{Og}$ så er vi tilbage ved debatten om behovet for at genopfinde den offentlige sektor.

\section{Iagttagelsesbegrebet}

Niklas Luhmann definerer iagttagelse som en operation, der markerer en side af en forskel og ikke en anden (Luhmann, 1993: 485). Pointen er, at den umarkerede side er lige så vigtig som den markerede, fordi den bestemmer, hvordan den iagttagede genstand viser sig for iagttageren. Idealet bliver med andre ord at give de studerende en indsigt $i$, hvordan deres valg af iagttagelse giver et særligt udsyn på organisationen og skaber særlige blinde pletter i forhold til andre udsyn på organisationen, og som samtidig er konstituerende for, hvad "organisationen" overhovedet bliver til. Lad os tage undervisning i organisationsteori som et eksempel. Når der undervises i bureaukratiet, markeres der en forskel mellem medarbejderens og lederens rolle. Lederen er den, der gennem regler udstikker en rolle til medarbejderen og medarbejderen er den, der tager rollen på sig. Bureaukratiet får netop denne betydning ved at være forskellig fra eksempelvis den lærende organisation, hvor lederen i højere grad forventes at supervisere og dermed være i øjenhøjde med medarbejderen. Hvad man kan iagttage er med andre ord afhængig af den forskel, der sætter rammen for iagttagelsen. Det vil sige med, Luhmanns iagttagelsesbegreb bliver det centrale ikke, ud fra en eller flere generaliserede modeller, at definere og diskutere, hvorvidt bureaukratiet er en organiseringsform, og den lærende organisation er et koncept. Det, der bliver centralt, er derimod at iagttage den forskel, vores forventninger om "organisationen" sætter. Alt bliver til et spørgsmål om at iagttage iagttagelser som iagttagelser, der sætter og konstituerer en forskel. I det følgende vil jeg folde ud, hvordan jeg tænker teknikkerne i figur 1 som en slags selvteknologi (Foucault, 1993). Forstået på den måde at jeg ikke ser dem som neutrale instrumenter til at få andre til at formidle eller anvende viden, men derimod som de generaliserede praksisser, der kan anråbe det enkelte subjekt som den, der kan iagttage sine (og andres) iagttagelser som iagttagelser, der skaber en konstituerende forskel.

\footnotetext{
${ }^{2}$ Hvorvidt dette i virkeligheden kan lade sig gøre, forholder denne artikel sig ikke til. Dens hovedærinde er at give et bud på, hvordan man kan bruge iagttagelsesbegrebet til at skabe betingelserne for en konkret undervisning.
} 


\section{Undervisningskonceptet - organisationen i et poststrukturalistisk perspektiv}

Sådan beskriver jeg undervisningen i undervisningsplanen:

\section{Figur 2}

\section{Mål:}

At introducere de studerende for hvordan man kan iagttage forholdet mellem organisation og individ på forskellige måder. Og at skabe en iagttagelsesstrategi der kan anskue, hvorledes de forskellige teorier og forestillinger om organisation og medarbejder har forskellige effekter for subjektivitet og magt og dermed for, hvordan ledelse overhovedet bliver mulig.

\section{Temaer/indhold:}

Undervisningen lægger ud med at tegne konturerne af Webers forestilling om den formelle organisation. Derfra spørger vi hvilke forestillinger om medarbejderen og organisationen, der er til stede, og hvilke effekter det har for ledelse.

På baggrund af Webers forestilling om bureaukratiet analyserer vi i grupper forskellige problemstillinger, som knytter sig til pædagogisk psykologiske praksisser, og spørger, hvordan Webers forestilling om bureaukratiet åbner forskellige løsningsmuligheder og, hvordan den skaber forskellige problemer.

Så træder vi et skridt tilbage gennem forelæsninger om andre og nyere teoretiske forståelser af forholdet mellem organisation og individ.

Herefter gennemføres nøjagtigt den samme $\varnothing$ velse men denne gang med en anden opfattelse af, hvad en organisation og et individ er. Det bliver nu tydeligt at et skift i metaperspektiv på organisation/individ ændrer på, hvad der er det organisatoriske problem og, hvad der er løsningsmulighederne.

Endelig vil vi forsøge at læse dagens undervisning bagfra med henblik på at oparbejde en iagttagelsesstrategi, der konstant kan gøre sig sensitiv overfor dets egen udsigelsesmulighed og refleksionskraft.

Som det burde fremgå sætter beskrivelsen af undervisningen tegn ${ }^{3} \mathrm{om}$, at de studerende bliver præsenteret for forskellige iagttagelser af, hvad en organisation er, og at de gennem øvelser skal afprøve, hvordan de forskellige iagttagelser producerer forskellige organisatoriske problemer og løsninger. Særligt introduktionen synes at være væsentlig, da den sætter tegn om, hvad de studerende kan forvente af undervisningen (for samme pointe se Meyer, 2005).

\footnotetext{
3 "At sætte tegn om" er en formulering, jeg bruger til at understrege den poststrukturalistiske pointe, at en beskrivelse af en undervisning ikke kun er en neutral beskrivelse af en begivenhed, der skal finde sted. Det er også en beskrivelse, der er med til at skabe betingelserne for den.
} 


\section{Konstruktionen af underviseren som leder af anden ordens iagttagelser}

Udover at præsentere mig selv begynder jeg som noget af det første, at fortælle om en personlig oplevelse jeg havde på et kursus i performance. Jeg fortæller eksempelvis:

"....en af de figurer, som gik igen på kurset, var en figur, som vi fik at vide kunne ligne Gandalf fra filmen Ringenes Herre. Helt konkret fik vi til opgave at lukke øjnene og at forestille os, at vi havde et brlte på af mod, en kappe af rummelighed, en krone af visdom som altid var til vores rådighed og en magisk stav $i$ hånden, der angav, at man altid ved, hvor man skal hen. Og når vi havde visualiseret, at vi var denne figur betød det, at vi kunne iagttage os selv og andre fra vores ekstraordinære tilstand. Visualiseringerne blev også brugt på andre tidspunkter. [...] Jeg skulle eksempelvis lagge mig på maven foran de andre, mens jeg hørte klassisk musik, og så skulle jeg forestille mig, at jeg løb ude i dyrehaven, og at jeg løb og løb og endelig fløj af sted, og at alt var så let så let. Og fra denne visualisering skulle jeg så begynde at rejse mig op igen og fortsætte den historie, jeg var i gang med. Og denne gang var stemmen en helt anden lige såvel, som tempoet var et helt andet. Og sådan var det med hver eneste øvelse og deltager...".

Der var flere grunde til, at jeg startede undervisningen med fortællingen om dette ekstraordinære kursus. Først og fremmest brugte jeg den til at illustrere undervisningens centrale omdrejningspunkt nemlig, at eksplosionen af styringsteknologier i den offentlige sektor sætter forholdet mellem organisationen og medarbejderen på spil, og at vi dermed ikke længere kan vide os sikre på, hvad en organisation og et medlemskab er (Andersen \& Born, 2004; Rennison, 2004; Raffnsøe, 2004; Pedersen, 2008; Rose, 1999; Dean, 1999). Pointen er, at det gør det interessant at kunne analysere, hvordan forskellige styringsteknologier iagttager og skaber præmisserne for, hvordan man kan iagttage organisationen og ledelse. Det forsøger jeg eksempelvis at understrege ved at afrunde historien på følgende måde: "Ser vi på dette i en organisationskontekst, bliver magt eller ledelse altså ikke (længere kun) muliggjort gennem lederens ordrer og instrukser, det bliver derimod muliggjort ved, at medarbejderen anspores til at skabe sig selv som ekstraordinær. Det er, når medarbejderen ser sig selv og andre som ekstraordinære, at den ekstraordinære og innovative organisation skabes. Det er selve forestillingen om det ekstraordinære, der muliggør ledelse".

Jeg bruger med andre ord fortællingen om visualiseringerne som en måde, hvorpå jeg søger at få dem til at gå med på den udfordring, at organisationsteori ikke længere (kun) handler om at forstå organisationen ud fra teorier, der på forhånd lægger sig fast på, hvad en organisation er. Derimod påstår jeg, at det handler om at kunne iagttage, hvorvidt og hvordan forskellige styringsteknologier iagttager og dermed også skaber organisationen og dens indbyggere. Dette syn på organisationens tilblivelse 
understøtter jeg desuden gennem diagnoser om eksempelvis den polyfone organisation (Andersen, 2001). Jeg kunne have valgt udelukkende at starte undervisningen med at henvise til, at "videnskabelige studier viser, at organisationer er polyfone og derfor taler med mange sideordnede stemmer". Når jeg ikke udelukkende gjorde brug af den mere traditionelle akademiske diskurs, var det ud fra en antagelse om, at en personlig fortælling kan vise, hvordan den polyfone organisation ikke kun bliver til gennem det, vi genkender som rationelle eller instrumentelle ledelsesdiskurser. Den bliver også til gennem vores egne iagttagelser af den.

\section{Konstruktionen af de studerende, der kan forstyrre deres egne og andres blikke} I forsøget på at skærpe de studerendes blik for, hvordan deres blikke på vores organisationer er med til at producere et særligt udsyn på organisationen og på, hvad der udpeges som udfordringer og løsninger, valgte jeg at gennemgå nogle forholdsvis karikerede perspektiver på, hvad en organisation er. Valget af teorier om organisationen blev: den bureaukratiske organisation, den feministiske organisation og den poststrukturelle/polyfone organisation. Jeg byggede særligt billederne af den bureaukratiske og den feministiske organisation op med hjælp fra Morgans Images of Organizations (Morgan, 2007). I min gennemgang af de forskellige perspektiver valgte jeg at fastholde fire centrale temaer som dem, der kan sige noget om, hvad en organisation er: Nemlig medlemskab, organisation, ledelse og ledelsesmetoder. Ved at skifte mellem de tre forskellige perspektiver, men samtidig fastholde blikket på nogle gennemgående temaer, ønskede jeg at reducere kompleksiteten. Tanken var, at det skærper deres mulighed for at iagttage forskellene på de forskellige perspektiver $\mathrm{i}$ forhold til, hvordan de skaber og iagttager udfordringer på særlige måder. Endelig var det væsentligt, at de studerende knyttede an til de første to teoretiske positioner, da den sidste position "den polyfone organisation" i højere grad forstyrrer billedet af, hvordan vi traditionelt forstår organisation som en enhed "derude", der har en entydig defineret grænse, der udpeger roller og kan afdækkes med de rette metoder. Startede jeg for tidligt med at gå i dybden med tekster, der forstyrrer forståelsen af organisationen som en afgrænset enhed, ville der være en risiko for, at de studerende ikke ville gå med på legen og præmisserne for undervisningen. Det ville minimere deres mulighed for at kunne iagttage og opleve, hvordan den iagttagede genstand, her organisationen, forandrer sig, når de studerende forskyder deres blik på den. Undervisningen og dens indhold var således også bygget op omkring en bevægelse, der gik fra at være mere genkendelige blikke på organisationer til at blive mere og mere forstyrrende blikke på forestillingen om organisationen som en fastdefineret enhed, der findes "derude" i virkeligheden adskilt fra vores iagttagelser. Den konstante forskydning af blikket på organisationen skulle anspore de studerende til at få øje på, hvordan de præsenterede teorier ikke er neutrale afspejlinger af virkelige organisationer men derimod er med til at skabe særlige organisatoriske udsyn, roller 
og ledelsesmuligheder. Det var forsøg på hele tiden at forstyrre iagttagelsen ved at gå fra første til anden - til tredje - ordens iagttagelser af organisationen. $\mathrm{Nu}$ vil jeg forsøge at vise, hvordan jeg forsøgte at skabe præmisserne for, at de selv begyndte at iagttage deres "egne" iagttagelser som iagttagelser, der skaber organisationens problemer og løsninger.

\section{Refleksionsøvelser - når iagttagelsesmaskinen sættes i spil}

Hver præsentation af en organisationsfigur blev afsluttet med den samme type refleksionsøvelse. Refleksionsøvelsen var bygget op omkring en sag, der netop på det tidspunkt havde stor opmærksomhed i medierne og som handlede om, at en journalist, der arbejdede undercover på en institution for mentalt handicappede, havde afsløret, hvordan pædagogerne havde talt nedsættende og aggressivt til beboerne. Jeg kaldte det "Strandvænget-casen". Jeg havde valgt denne case ud fra en viden om, at mange af de studerende kendte til de problematikker, der er forbundet med denne case. Kendetegnende for mange af de DPU-studerende på kandidatuddannelsen i pædagogisk psykologi er, at de er uddannet som professionsbachelorer og har flere års erfaring som socialrådgivere, pædagoger og lærere. Tanken var, at det skulle være en case, som de studerende personligt kunne involvere sig i, og at de skulle opleve, hvordan de forskellige blikke på organisationen kan forskyde deres 'personlige' udsyn på problematikken og åbne op for nye perspektiver på, hvad udfordringerne og problemerne er. Udover at præsentere casen og den problemstilling den rejste i medierne, valgte jeg også at italesætte dem som en ekspertgruppe af ledere, der skulle komme med et bud på, hvordan problemerne kunne løses. Jeg skrev på planchen: "Regionsformand Carl Holst, har nu besluttet at nedsætte jer som en ekspertarbejdsgruppe. Han udtaler til medierne: "Vi vil nu nedsætte en arbejdsgruppe med eksperter fra regionen, institutionerne og uddannelsessteder, som inden udgangen af april skal fremlægge en plan for, hvordan vi udvikler den pxdagogiske indsats i regionens tilbud til voksne udviklingshæmmede", regionsformand Carl Holst". Det vil sige, når jeg inddelte de studerende i grupper, så var det med henblik på, at de skulle anråbe sig selv som en ekspertgruppe. I denne gruppe skulle de først og fremmest svare på: "Diskutér med afsæt i den formelle organisation Strandvænget-sagen i forhold til følgende punkter: Hvad er problemet? Hvilke ressourcer/tiltag skal stilles til rådighed med henblik på at løse problemet? Hvilke egenskaber/kvalifikationer skal beslutningstageren have?") Spørgsmålene skulle lægge an til, at de studerende anvendte den formelle/bureaukratiske organisation som et udsyn på de problematikker, som Strandvænget-sagen producerede. I første omgang skulle de studerende således ikke reflektere over, hvad det betyder at iagttage organisationen fra den formelle organisation og dermed hvilket udsyn og blinde pletter, det producerer. De skulle 'bare' anvende perspektivet til at diskutere mulige løsninger. Øvelsen blev gentaget med den feministiske organisation. Pointen med at italesætte dem som ekspertgruppe var at få dem til at knytte an til idéen med øvelsen 
ved at føle sig betydningsfulde. Gik de udenfor den iagttagende forskel, som netop blev muliggjort gennem præsentationen af den bureaukratiske og den feministiske organisation, ville de miste de muligheden for at kunne iagttage den forskel, den konkrete teoretiske iagttagelse gør i forhold til at se og løse organisatoriske problemer. Kort sagt tilrettelagde jeg denne øvelse ud fra en præmis om, at man må iagttage på første orden, før man på anden orden kan iagttage, hvordan første ordens perspektiverne gør en forskel for, hvordan organisationen bliver til.

\section{Spejlinger i grupper - et medie til at installere iagttagelsesmaskinen}

Herefter bad jeg de studerende om at spejle deres svar i en anden gruppes svar. De studerende blev efter hver øvelse bedt om at skrive deres svar på plancher. På den måde kunne planchen 'fastfryse' deres svar og bruges til at formidle dem til en anden gruppe. Idéen var, at de studerendes fremlæggelser for hinanden, af henholdsvis den bureaukratiske og den feministiske organisations syn på Strandvænget-sagen, skulle synliggøre, hvordan de forskellige præmisser for at iagttage problemer er med til at forme løsningerne. Det skulle med andre ord være en metode til at vise, at den enkelte gruppes svar måske nok var originale, men at deres specifikke teoretiske iagttagelse af organisationen sætter en grænse for, hvordan man overhovedet kan løse de organisatoriske udfordringer. Spejlingen i grupper var således en måde, hvorpå jeg ønskede at få de studerende til selv at opleve, hvordan valget af det teoretiske perspektiv gør en forskel for de udfordringer, man ser, uden at jeg skulle påtage mig en faglig autoritet og fremføre og understrege det gennem referencer til eksempelvis såkaldt videnskabelige studier. Trækker man pointen lidt længere, var det en måde, hvorpå jeg ville anspore de studerende til ikke blot at få kendskab til diskursive analysestrategier (Andersen, 1999), der kan iagttage organisationer på forskellige måder. Jeg ville også gøre dem til 'selv-refleksive iagttagelsesmaskiner', der har blik for, at deres valg af iagttagelser producerer særlige udsyn på organisationen og dens medlemmer og dermed producerer særlige problemer og mulige løsninger. Ambitionen om at gøre dem til "selv-refleksive-iagttagelsesmaskiner", handlede igen om at ruste dem til fremadrettet selv at kunne reflektere over, hvilke iagttagelser de selv vil vælge og hvilke konsekvenser det har for, hvordan vi genopfinder, skaber og former den offentlige sektor.

\section{Poststrukturalistiske iagttagelser af organisationen}

Det sidste blik på organisationen, som de studerende skulle anvende, var det, jeg valgte at kalde et poststrukturalistisk perspektiv på organisationen. Her ville jeg anspore de studerende til at trække deres iagttagelser og deres viden om den bureaukratiske og den feministiske organisation tilbage. I stedet ville jeg anspore dem til at knytte an til den præmis, at deres brug af forskellige analysestrategier iagttager og skaber organisationen på forskellige måder og udelukker andre. Tanken var, at de i 
de foregående øvelser allerede havde banet vejen for den præmis, og at jeg nu kunne begynde at italesætte den eksplicit ved at henvise til forskellige videnskabelige, poststrukturalistiske studier. Således fremlagde jeg, hvordan de poststrukturalistiske studier af organisationer gør op med metoder til afdækning af viden 'derude' og i stedet taler om teori som diskursive analysestrategier, der kan iagttage og skabe noget og ikke noget andet (Andersen, 1999). Efter nogle eksempler på diskursive analysestrategier i forhold til konkrete studier, var det tanken, at de studerende selv skulle afprøve analysestrategierne i grupper i forhold til to små avisartikler om Strandvænget-sagen. Spørgsmålene lød nu: Analysér Strandvænget-sagen med udgangspunkt $i$ et eller flere spørgsmål: Hvilke styringsteknologier italesættes - og hvordan former de forholdet mellem organisationen/medarbejderen? Hvilke sociale kategorier (køn, alder, funktion m.m.) italesættes, og hvilke in- og ekskluderes? Hvem eller hvad udpeges som dem, der har ansvar for inklusion? Den øvelse viste sig at være markant sværere for de studerende end de to øvrige. Det gav sig udslag i, at de studerende i højere grad søgte min hjælp, når jeg gik rundt mellem grupperne. For nogle af grupperne lykkedes det at producere egentlige svar på spørgsmålene. Andre grupper brugte mere tid på at diskutere spørgsmålene og på at afsøge, hvad det egentlig betyder at stille spørgsmål på denne måde. Da grupperne kom tilbage i plenum gav jeg mit bud på, hvordan en analyse af avisartiklerne kunne se ud og dermed også mit bud på, hvordan artiklerne gennem deres valg af iagttagelse på "sagen" producerede organisationen på en særlig måde. De udpegede helte og skurke i den konkrete case og producerede 'nye' problemer og løsninger. Det var et forsøg på at illustrere, hvad perspektivet kan, men også et forsøg på at skabe refleksioner om, hvad det valgte perspektiv ikke kan iagttage. Pointen med Strandvænget-casen var således ikke, at det var en case, hvormed de studerende skulle diskutere for og imod, hvad de oplevede som den sande og adækvate beskrivelse af "hvad der i virkeligheden skete". "Casen" blev udelukkende brugt til at anspore de studerende til at få blik for, hvordan de forskellige teoretiske perspektiver har betydning for, de ledelsesudfordringer og de løsninger de udpeger og giver.

\section{At læse undervisningen bagfra}

Jeg afsluttede undervisningsdagen ved at anspore de studerende til at læse undervisningen bagfra. De skulle med andre ord også iagttage undervisningen som iagttagelser af iagttagelser af iagttagelser. Jeg spurgte således ud i lokalet: Hvordan har undervisningen sat præmisserne for vores iagttagelse af organisation og ledelse? På tavlen tegnede jeg et sildeben (se også Andersen, 1999) over de tre forskellige analysestrategier (den bureaukratiske, den feministiske og den poststrukturalistiske) og jeg endte med at italesætte, at de tre strategier ikke skulle læses som tegn på, at nogle strategier var bedre end andre, men som forskellige og ligestillede måder at iagttage organisationen på, som vi gentager og citerer i forskellige sammenhænge. I forlæn- 
gelse heraf afrundede jeg med, at hvis man vil se sine egne blinde pletter, når man vil iagttage organisationer og dens problemer og løsninger som medarbejder eller leder, ja så må man træde et skridt tilbage ved at spørge, hvilken iagttagelsesposition ser jeg nu organisationen ud fra - hvilken forskel sætter jeg?

\section{Afsluttende kommentarer}

Spørgsmålet er nu: Kan denne form for design af undervisning skabe de ledere (og medarbejdere), der kan håndtere styringspresset, polyfonien og de uddifferentierede og flydende systemer? En rapport der evaluerer en Diplomuddannelse i Ledelse ved at spørge lederne om, hvordan de så bruger de faglige perspektiver, der også er centrale i denne artikel, efter uddannelsesforløbet, svarer ja (Weinreich, Stæhr \& Mikkelsen, 2011). Lederne bliver bedre til strategisk at navigere i organisationer. De kan i højere grad proaktivt vælge deres iagttagelser og dermed, hvilken kasket og hvilket udsyn de har på organisationen og reflektere over iagttagelsens blinde pletter. Men et er, at de strategisk kan navigere i landskabet ved at have øje for, hvordan de selv (og andre) er med til at skabe det. Noget andet er, hvorvidt deres kompetence til at skabe proaktive strategier egentligt er med til at genopfinde den offentlige sektor? Det siger evalueringsrapporten - såvel som denne artikel - ikke noget om. Nærværende artikel siger udelukkende noget om, hvordan man kan "skrue op" for præmissen om, at vi selv er med til at skabe organisationen gennem vores valg af iagttagelse ved ikke kun at undervise i poststrukturalistiske tekster om ledelse men også ved at undervise på poststrukturalistisk. Hvis vi ikke vil lege med iagttagelser af iagttagelser som iagttagelser, der skaber organisatoriske udsyn og ledelseskasketter, må vi teoretisk stå et helt andet sted. Og sådan ender denne artikel - som undervisningen med at læse sig selv bagfra. Den ender med at ville forstyrre sine egne præmisser.

Christa Breum Amhøj er ansat som seniorforsker på CBS i SLIP-programmet, der har til formål at genopfinde ledelse af den offentlige sektor gennem eksperimenterende forskning. Hun er tidligere adjunkt på DPU og ph.d. i Management of Technologies fra Copenhagen Business School.

\section{Litteraturliste}

Amhøj, C. B. (2007). Det selvskabte medlemskab - om managementstaten, dens styringsteknologier og indbyggere. Forskerskolen i Ledelsesteknologi. CBS. Ph.D. serie 23. 2007.

Andersen, N. Å. (1999). Diskursive analysestrategier, København: Nyt fra samfundsvidenskaberne s. 197.

Andersen, N. Å. (2001). "Polyfone organisationer", CCC Working Paper, no. 6, 2001, 26 sider.

Andersen, N. Å., \& Born, A. (2001). Kærlighed og omstilling. Italesættelsen af den offentlige ansatte. København: Nyt fra samfundsvidenskaberne. 
Andersen, N. Å., \& Thygesen, N. T. (2004). "Styring af styringsværktøjer". Nordisk Administrativt tidsskrift, 1/2004, vol. 85.

Andersen, N. Å., \& Thygesen, N. T. (2004). "Styringsteknologier i den selvudsatte organisation", GRUS 73, vol. 25.

Andersen, N. A. (2003). "Organisation i anden ordens perspektiv - systemteoriensanalysestrategiske maskine“", in Højlund, Holger \& Knudsen, Morten. Organiseret kommunikation - systemteoretiske analyser. Københaven: Samfundslitteratur, pp. 310-323.

Argyris, C., \& Schön, D. (1996). Organizational Learning II: Theory, Method, and Practice. Reading MA: Addison-Wesley.

Argyris, C., \& Schön, D. (1978). Organizational Learning: A Theory of Action Perspective. Reading MA: Addison-Wesley.

Dean, M. (1999). Governmentality - power and rule in modern society. SAGE Publication s. 304.

Foucault, M. (1997). Ethics-subjectivity and truth, Essential works of Foucault 19541984, nr, 1. London: The Penguin Press.

Helth, P. (red.) (2011): Ledelse og læring i praksis. København: Samfundslitteratur.

Keller, H., Willert, S., \& Stegeager, N. (2011). "Efteruddannelse som ledelsesudfordring - på sporet af en akademisk praksisuddannelse", in Helth. P. (red.). Ledelse og læring i praksis.

Luhmann, N. (1993). "Observing Re-entries", in Graduate Faculty Philosophy Journal. New York: Department of Philosophy. The New School for Social Research, pp. 485-498.

Melander, Preben (red.) (2008). Det fortrængte offentlige lederskab - offentlig ledelse efter New Public Management. 1. udgave, Jurist- og Økonomforbundets Forlag.

Meyer, H. (2005). Hvad er god undervisning? København: Gyldendal.

Pedersen, D., \& Nielsen, J. C. R. (2011). "Deltagerorienteret lederuddannelse", in Helth, P. (red.): Ledelse og Læring i praksis.

Pedersen, D. (red.) 2004: Offentlig ledelse i managementstaten. Forlaget Samfundslitteratur.

Pedersen, D., Højlund. H., \& Greve, C. (red.) (2008). Genopfindelsen af den offentlige sektor Ledelsesudfordringer i reformens tegn. København: Børsens Forlag, s. 352.

Pedersen, O. K. (2011). Konkurrencestaten. København: Hans Reitzels Forlag.

Raffnsøe, S. (2004). "Ledelse, styring og stat fra antikken til moderne tid", in Offentlig ledelse i managementstaten. København: Forlaget Samfundslitteratur.

Rennison, B. (2004). "Ledelsesbegrebets historie i den offentlige sektor", in Offentlig ledelse i managementstaten. København: Forlaget Samfundslitteratur.

Rose, N. (1999). Powers of Freedom. Reframing Political Thought. Cambridge: Cambridge University Press.

Schön, D. (1987). Educating the Reflective Practitioner. San Francisco: Jossey-Bass.

Sløk, C., \& Villadsen, K (red.) (2008). Velfærdsledelse - i den selvstyrede stat. København: Hans Reitzels Forlag. 
Tangkjær, C., \& Thygesen, N. T. (2008). "Ledelse af styringspresset. To normative nedslag" i Sløk, C. \& Villadsen, K. (red.), Velfærdsledelse i den selvstyrende velfærdsstat. København: Hans Reitzels Forlag.

Weinreich, E., Stæhr, M., \& Mikkelsen, P. N. (2011). Professionalisering af ledelse; effekter og spor. En undersøgelse af Ringsted Kommunes lederudviklingsprojekt. Professionshøjskolen. UCC. 